Original Article

\title{
EVALUATION OF CYTOTOXIC ACTIVITY AND ANTHELMINTIC PROPERTY OF CHLOROFORM EXTRACT OF CLITORIA TERNATEA L.
}

\author{
LAKSHMI KANTA KANTHAL*, ADARI VENKATA RAJULU NAIDU, PILLA NAGA LAKSHMI, YADALA BABURAO, \\ KAUSIK BHAR
}

Koringa College of Pharmacy, Department of Pharmacology, Korangi 533461, Tallarevu Mandal, Andhra Pradesh, India

Email: lkkhaldia@gmail.com

Received: 25 Jul 2016, Revised and Accepted: 17 Sep 2016

ABSTRACT

Objective: The objective of the present work was to evaluate the phytochemical study, cytotoxic activity and anthelmintic property of the whole plant chloroform extract of Clitoria ternatea $L$.

Methods: The chloroform extract was tested for protein, amino acids. alkaloids, glycosides, flavonoids, tannins, steroids, saponins. The in vitro cytotoxic activity of chloroform extract was performed by MTT assay method against HepG2 (Liver carcinoma), HeLa (Cervix carcinoma) cell lines. 25, 50 and $100 \mathrm{mg} / \mathrm{ml}$ concentration of chloroform extract of Clitoria ternatea $L$. whole plant were taken for performing anthelmintic activity against adult Indian earthworm Pheritima posthuma.

Results: The preliminary phytochemical tests revealed that chloroform extract of Clitoria ternatea L. contains amino acids, alkaloids, glycosides, flavonoids, tannins, saponins, steroids. Effect of inhibition of cell growth showed significant cytotoxicity against HepG2 with an IC50 of $110.00 \pm 1.9$ $\mu \mathrm{g} / \mathrm{ml}$ and against HeLa with an IC50 of $104.50 \pm 0.9 \mu \mathrm{g} / \mathrm{ml}$. The crude chloroform extract $(25,50,150 \mathrm{mg} / \mathrm{ml}$ concentration) of Clitoria ternatea $L$. whole plant shows potent anthelmintic activity against Pheritima posthuma.

Conclusion: The present study concluded that Clitoria ternatea L. can be considered as an important source of natural products that have anticancer potentials and potent anthelmintic activity.

Keywords: Clitoria ternatea L., Chloroform extract, Cytotoxic activity, Anthelmintic activity

(C) 2016 The Authors. Published by Innovare Academic Sciences Pvt Ltd. This is an open access article under the CC BY license (http://creativecommons.org/licenses/by/4.0/) DOI: http://dx.doi.org/10.22159/ijcpr.2016v8i4.15282

\section{INTRODUCTION}

In the recent past, there has been a growing interest in Traditional medicine/Complementary and Alternative Medicine (TCAM) and their relevance to public health both in developed and developing countries. Herbal medicines include herbs, herbal materials, herbal preparations and finished herbal products that contain parts of plants or other plant materials as active ingredients [1]. The anticancer property of nutrients derived from plants as well as non-nutritive plant derived constituents has been proved in different in vitro and in vivo models [2]. Clitoria ternatea $\mathrm{L}$. is a very bioactive plant and used in various diseases as folklore medicine $[3,4]$. A Recent study showed that it has anxiolytic, antidepressant, anticonvulsant and anti-stress activity [5]. The herb has the property to increase the strength of the body. Clitoria ternatea $L$. is often grown as an ornamental plant. They require little care for cultivation. The plants have the property to improve the soil quality [6].

This plant has a long use in traditional Ayurvedic medicine for several diseases, and the scientific study has reconfirmed those with modern relevance. This review is an effort to explore the chemical constituents, pharmacological and toxicity studies of CT, which have long been in clinical use in the Ayurvedic system of medicine along with a critical appraisal of its future ethnopharmacological potential in view of many recent findings of importance on this well-known plant species [7]. The roots, leaves, and stems are all frequently used in Ayurveda, but for slightly different purposes. The roots are most widely used and are bitter, refrigerant, laxative, intellect promoting, diuretic, anthelmintic and tonic and are useful in dementia, hemicrania, burning sensation, leprosy, inflammation, leucoderma, bronchitis, asthma, pulmonary tuberculosis, ascites and fever. The seeds are cathartic, while the leaves are used in otalgia and hepatopathy [8].

\section{MATERIALS AND METHODS}

\section{Plant material}

The whole plants of Clitoria ternatea L. were collected from local areas of Korangi, Kakinada, East Godavari Dist., Andhra Pradesh. The plant was identified and authenticated by Mr. P. Venu, Additional Director, BSI, Deccan regional centre, Hyderabad-500048 where a voucher specimen has been deposited.

\section{Preparation of extract}

The whole plant parts of Clitoria ternatea L. were shade dried at room temperature, powdered and passed through 60 mesh size sieves. 215 gms of powdered plant parts were weighed accurately and extracted with chloroform solvent $(1200 \mathrm{ml})$ using cold maceration method. Thus obtained extract were filtered through Whatman No.1 filter paper and the filtrate was concentrated. The extract ( $2.3 \mathrm{~g}$ ) was transferred to sterile screw cap bottles, labeled and stored in the refrigerator until use.

\section{Preliminary phytochemical screening}

The chloroform extract of Clitoria ternatea was tested for protein amino acids. alkaloids, glycosides, flavonoids, tannins, steroids, saponins [9-15].

\section{Cytotoxic activity}

Chemicals

3-(4,5-dimethyl thiazol-2-yl)-5-diphenyltetrazolium bromide (MTT), Fetal Bovine serum (FBS), Phosphate Buffered Saline (PBS), Dulbecco's Modified Eagle's Medium (DMEM) and Trypsin were obtained from Sigma-Aldrich Co, St Louis, USA. EDTA, Glucose and antibiotics from Hi-Media Laboratories Ltd., Mumbai. Dimethyl Sulfoxide (DMSO) and Propanol from E. Merck Ltd., Mumbai, India. 


\section{Cell lines and culture medium}

HepG2 (Liver carcinoma), HeLa (Cervix carcinoma), cell lines were procured from National Centre for Cell Sciences (NCCS), Pune, India. Stock cells were cultured in DMEM supplemented with 10\% inactivated Fetal Bovine Serum (FBS), penicillin (100 IU/ml), streptomycin $(100 \mu \mathrm{g} / \mathrm{ml})$ and amphotericin B $(5 \mu \mathrm{g} / \mathrm{ml})$ in an humidified atmosphere of $5 \% \mathrm{CO}_{2}$ at $37^{\circ} \mathrm{C}$ until confluent. The cells were dissociated with TPVG solution $(0.2 \%$ trypsin, $0.02 \%$ EDTA $0.05 \%$ glucose in PBS). The stock cultures were grown in $25 \mathrm{~cm}^{2}$ culture flasks and all experiments were carried out in 96 microtitre plates (Tarsons India Pvt. Ltd., Kolkata, India).

\section{Preparation of test solutions}

For cytotoxicity studies, each weighed test drugs were separately dissolved in distilled DMSO and volume was made up with DMEM supplemented with $2 \%$ inactivated FBS to obtain a stock solution of $1 \mathrm{mg} / \mathrm{ml}$ concentration and sterilized by filtration. Serial two-fold dilutions were prepared from this for carrying out cytotoxic studies.

\section{Determination of cell viability by MTT assay}

The monolayer cell culture was trypsinized and the cell count was adjusted to $1.0 \times 105$ cells/ml using DMEM containing 10\% FBS. To each well of the 96 well microtitre plate, $0.1 \mathrm{ml}$ of the diluted cell suspension (approximately 10,000 cells) was added. After $24 \mathrm{~h}$, when a partial monolayer was formed, the supernatant was flicked off; the monolayer was washed once with medium, and $100 \mu$ lof test different concentrations of extracts were added on to the partial monolayer in microtitre plates. The plates were then incubated at 37 o C for $3 \mathrm{~d}$ in 5\% CO2 atmosphere, and microscopic examination was carried out and observations were noted every $24 \mathrm{~h}$ interval. After $72 \mathrm{~h}$, the sample solutions in the wells were discarded and $50 \mathrm{l}$ of MTT in PBS was added to each well. The plates were gently shaken and incubated for $3 \mathrm{~h}$ at 37o C in 5\% CO2 atmosphere. The supernatant was removed and $100 \mathrm{~L}$ of propanol was added and the plates were gently shaken to solubilize the formed formazan. The absorbance was measured using a microplate reader at a wavelength of $540 \mathrm{~nm}$ [16]. The percentage growth inhibition was calculated using the following formula and concentration of test sample needed to inhibit cell growth by $50 \%\left(\mathrm{IC}_{50}\right)$ is generated from the dose-response curves for each cell line [17].

$\%$ Growth Inhibition $=100-\{($ Mean OD of individual test group/Mean OD of control group) $\times 100\}$

\section{Anthelmintic activity}

The anthelmintic activity was performed according to the standard method [18] on the adult Indian earthworm Pheritima posthuma. Mebendazole, the standard drug, was diluted with normal saline to obtain 25,50 and $100 \mathrm{mg} / \mathrm{ml}$ concentrations and was poured into Petri dishes. Chloroform extract of the plant was diluted with normal saline to obtain 25,50 and $100 \mathrm{mg} / \mathrm{ml}$ concentrations. Normal saline $(0.9 \% \mathrm{NaCl})$ alone served as the negative control. All these dilutions were poured into the Petri dishes accordingly. Seven petridishes of equal size were taken and numbered. Six earthworms $(\mathrm{n}=6)$ of similar sizes (about $8 \mathrm{~cm}$ ) were placed in each petridish at room temperature. Time for paralysis was noted down when no movement of any sort could be observed, except when the worms were shaken vigorously. Time of death for worms was recorded after ascertaining that the worms neither moved when shaken vigorously nor when dipped in warm water $(50$ o $\mathrm{C}$ ). The paralysis time and lethal time were recorded in terms of minutes.

\section{RESULTS AND DISCUSSION}

The preliminary phytochemical study revealed that chloroform extract of Clitoria ternatea $L$. contains amino acids, alkaloids, glycosides, flavonoids, tannins, saponins, steroids.

In performing cytotoxic activity, There was gradual increase in the value of PGI (percentage of growth inhibition) as the concentration of extract was increased $(39.68,51.06,60.92,68.95,78.00 \%$ for the concentrations $62.5,125,250,500,1000 \mu \mathrm{g} / \mathrm{ml}$, respectively) against the HepG2 cell line (fig. 1) and (37.01, 55.76, 66.93, 87.31, $92.81 \%$ for the concentrations $62.5,125,250,500,1000 \mu \mathrm{g} / \mathrm{ml}$, respectively) against HeLa cell line (fig. 2). The median value of IC50 observed for HepG2 and HeLa cell lines were $110.00 \pm 1.9$ and $104.50 \pm 0.9$ respectively.

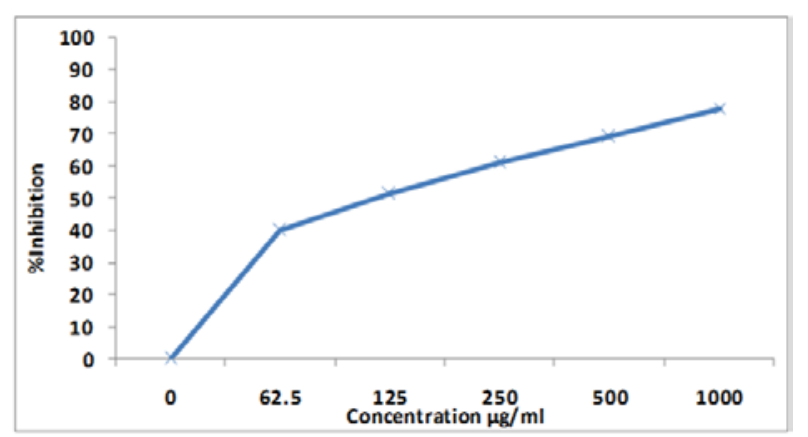

Fig. 1: Cytotoxic activity of Clitoria ternatea L. on HepG2 cell line

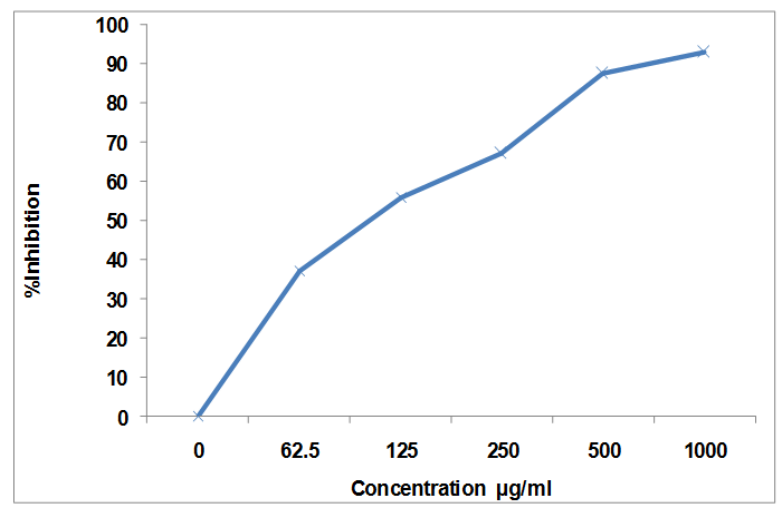

Fig. 2: Cytotoxic activity of Clitoria ternatea L. on HeLa cell line

The result of anthelmintic activity shows (table 1) that for the 25 $\mathrm{mg} / \mathrm{ml}$ concentration, Mebendazole showed the best activity for death time $(76.3 \pm 2.3 \mathrm{~min})$ and the chloroform extract of Clitoria ternatea showed a death time of $97.0 \pm 2.0 \mathrm{~min}$. Also, for the 50 $\mathrm{mg} / \mathrm{ml}$ concentration, Mebendazole showed the highest activity against the worms $(65.3 \pm 1.5 \mathrm{~min})$ and the chloroform extract of Clitoria ternatea showed a death time of $75.0 \pm 2.0 \mathrm{~min}$. For the 100 $\mathrm{mg} / \mathrm{ml}$ concentration, Mebendazole showed the least death time $47.0 \pm 2.0 \mathrm{~min}$ and the chloroform extract of Clitoria ternatea showed a death time of $65.5 \pm 1.5 \mathrm{~min}$.

Table 1: In vitro anthelmintic effect of Clitoria ternatea $L$. against Pheritima Posthuma

\begin{tabular}{llll}
\hline Treatment & Concentration $\mathbf{( m g / m l )}$ & Paralysis time (min) & Death time (min) \\
\hline Mebendazole & 25 & $62.6 \pm 2.5$ & $76.3 \pm 2.3$ \\
(standard) & 50 & $48.0 \pm 2.0$ & $65.3 \pm 1.5$ \\
& 100 & $33.0 \pm 3.0$ & $47.0 \pm 2.0$ \\
Chloroform extract of Clitoria & 25 & $76.0 \pm 3.0$ & $97.0 \pm 2.0$ \\
ternatea L & 50 & $66.0 \pm 2.0$ & $75.0 \pm 2.0$ \\
& 100 & $48.0 \pm 2.6$ & $65.5 \pm 1.5$ \\
\hline
\end{tabular}

\pm SD value, $n=3$. 


\section{CONCLUSION}

In conclusion, the present plant Clitoria ternatea L. can be considered as an important source of natural products that have anti-cancer potentials and potent anthelmintic activity, due to the presence of various phytochemical components but it is too early to reach a final conclusion and further investigations are required to include further cell lines and worms, respectively.

\section{ACKNOWLEDGEMENT}

The authors are grateful to the management of Koringa College of Pharmacy, Korangi, East Godavari Dist., Andhra Pradesh, India for making available all the facilities.

\section{CONFLICTS OF INTERESTS}

\section{Declared none}

\section{REFERENCES}

1. Gupta SS. Prospects and perspectives of natural plant products in medicine. Indian J Pharmacol 1994;26:1-12.

2. Barnes S. Effect of genistein on in vitro and in vivo models of cancer. J Nutr 1995;125 Suppl 3:777-83.

3. El-Gendy AR. Regional overview: eastern mediterranean region. WHO Global Atlas on Traditional, Complementary and Alternative Medicine, WHO Centre for Health and Development, Kobe; 2005. p. 153-8.

4. Farnsworth N. Screening Plants for New Medicines, Biodiversity. National Academy Press: Washington DC; 1988. p. 83-97.

5. McLaughlin JL. Bench-top bioassay for the discovery of bioactive compounds in higher plants. Brenesa 1990;34:1-14.

6. Fantz PR. Ethnobotany of Clitoria (Leguminosae). Economic Botany 1991;45:511-20.

7. Mukherjee PK, Kumar V, Kumar NS, Heinrich M. The ayurvedic medicine Clitoria ternatea from traditional use to scientific assessment. J Ethnopharmacol 2008;120:291-301.

8. Das B, Reddy VS, Krishnaiah M, Sharma AVS, Ravi Kumar K, Rao $\mathrm{JV}$, et al. Acetylated pseudo guaianolides from Parthenium hysterophorus and their cytotoxic activity. Phytochemistry 2007;68:2029-34.
9. Kumar GS, Jayaveera KN, Kumar CK, Sanjay UP, Swamy BM, Kumar DV. Antimicrobial effects of Indian medicinal plants against acne-inducing bacteria. Trop J Pharm Res 2007;6:717-23.

10. Parekh J, Chanda SV. In vitro antimicrobial activity and phytochemical analysis of some Indian medicinal plants. Turk J Biol 2007;31:53-8.

11. Edeoga HO, Okwu DE, Mbaebie BO. Phytochemical constituents of some Nigerian medicinal plants. Afr J Biotechnol 2005;4:685-8.

12. Akinyemi KO, Oladapo O, Okwara CE, Ibe CC, Fasure KA. Screening of crude extracts of six medicinal plants used in SouthWest Nigerian unorthodox medicine for anti-methicilin resistant Staphylococcus aureus activity. BMC Complementary Altern Med 2005;5:6.

13. Dahiru D, Onubiyi JA, Umaru, HA. Phytochemical screening and antiulcerogenic effect of Mornigo oleifera aqueous leaf extract. Afr J Tradit Complementary Altern Med 2006;3:70-5.

14. Harborne JB. Phytochemical Methods. $2^{\text {nd }}$ ed. New York, London: Springer, Chapman and Hall; 1984. p. 288

15. Wagner H, Baldt S, Zgainski EM. Plant drug analysis. Berlin/New York: Springer-Verlag; 1984.

16. Francis D, Rita L. Rapid colorimetric assay for cell growth and survival: modification to the tetrazolium dye procedure giving improved sensitivity and reliability. J Immunol Methods 1986;89:271-7.

17. Ali HA, Orooba NHA, Khulood WA. Cytotoxic effects of Agrimonia eupatoria L. against cancer cell lines in vitro. J Assoc Arab Univ Basic Appl Sci 2013;14:87-92.

18. Kanthal LK, Dey Akalanka, Satyavathi K, Bhojaraju P. Cytotoxic activity of Lactuca Runcinata DC and Gyrocarpus Asiaticus willd on cancer cell lines in vitro. Int J Pharm Pharm Sci 2014;6:457-60.

19. Kanthal LK, Dey Akalanka, Satyavathi K, Bhojaraju P. Evaluation of anthelmintic activity of Gyrocarpus asiaticus willd and Lactuca runcinata dc on the Pheritima, posthuma model. Int J Pharm Pharm Sci 2013;5:273-5.

\section{How to cite this article}

- $\quad$ Lakshmi Kanta Kanthal, Adari Venkata Rajulu Naidu, Pilla Naga Lakshmi, Yadala Baburao, Kausik Bhar. Evaluation of cytotoxic activity and anthelmintic property of chloroform extract of Clitorea ternatea L. Int J Curr Pharm Res 2016;8(4):73-75. 